\title{
Polymorphisms of Tumour necrosis factor-a-308 (rs 1800629) and gastric cancer susceptibility: A meta- analysis of associations studies with trial sequential analysis
}

\author{
Norah Htet Htet \\ International Medical University, Kuala Lumpur, Malaysia \\ Cho Naing ( $\sim$ cho3699@gmail.com) \\ International Medical University, Kuala Lumpur, Malaysia \\ Wong Siew Tung \\ International Medical University, Kuala Lumpur, Malaysia \\ Thin Thin Win \\ International Medical University, Kuala Lumpur, Malaysia \\ Joon Wah Mak \\ International Medical University, Kuala Lumpur, Malaysia
}

\section{Systematic Review}

Keywords: Gastric cancer, Risk factor, Tumour necrosis factor, Meta-analysis

Posted Date: January 21st, 2021

DOI: https://doi.org/10.21203/rs.3.rs-150936/v1

License: (c) (i) This work is licensed under a Creative Commons Attribution 4.0 International License. Read Full License 


\section{Abstract}

Background: Gastric cancer is globally the fifth most common cancer. Several studies have assessed the relationship between tumour necrosis factor-alpha (TNF-a- 308) and the risk of gastric cancer. These individual genetic association studies showed inconclusive results. The objective of the present study was to synthesis evidence on the association between TNF-a-308 polymorphisms and gastric cancer risk by meta-analysis of data from eligible studies.

Methods: We performed a meta-analysis of genetic association studies, according to the PLOS One checklist. We searched relevant case-control studies in health-related electronic databases. The methodological quality of included studies was assessed by the Newcastle-Ottawa quality assessment scale. The strength of association was calculated as odds ratios (ORs) with $95 \%$ confidence intervals (Cls). Pooled ORs and $95 \%$ Cls were estimated using randomeffects model or fixed effect model, based on between-study heterogeneity. We analysed the strength of association under four genetic models (allele, dominant, recessive and additive models). Subgroup analyses on ethnic groups, Hardy-Weinberg equilibrium (HWE) status, status of Helicobacter pylori infection and study quality were done for robustness of the estimates. Publication bias was detected by inspection of funnel plot asymmetry. To estimate the required information size, we performed trial sequential analysis (TSA) that classified the effect estimates as 'firm evidence of effect' or 'potentially spurious evidence of effect'.

Results: A total of 35 studies, comprising 11353 cases and 12827 controls were identified. Based on 28 studies that met HWE, there was overall significant association between TNF-a-308 polymorphisms and gastric cancer risk under the dominant model (OR 1.19, 95\% Cl 1.1-1.29, $P$ :37\%), as well as Asians (OR 1.2, $95 \% \mathrm{Cl} 1.05-1.38, P: 53 \%$ ) and Cassian subgroups (OR 1.19, 95\% Cl 1.07-1.31, R:28\%). Based on 13 high quality studies under the dominant model, overall significant association was also found (OR $1.38,95 \% \mathrm{Cl} 1.07,1.77)$. The TSA plot indicated the analyses was with the required information size. There was no publication bias. In the subgroup analysis by ethnic groups, the quality of studies impacted on the estimates.

Conclusions: The findings suggest that TNF- $a-308$ gene polymorphism plays an important predisposing role for gastric carcinogenesis, and can serve as a useful screening marker.

\section{Introduction}

Gastric cancer (ICD10: C16) is globally the fifth most common cancer with the highest prevalence in both sexes in Asia (74.5\%) and the third leading cause of cancer death. In 2018, the estimated number of deaths attributed to gastric cancer was 782,685 [1]. As such, a greater understanding of the risk factors that play a role in gastric carcinogenesis can improve preventive and therapeutic interventions [2].

Epidemiologic studies showed that gastric cancer is multifactorial in aetiology [3, 4], in which dietary factors and Helicobacter pylori infection may contribute to its development [3]. Of note is that a high prevalence of these risk factors do not always correspond to a high incidence of gastric cancer, suggesting that other susceptible factors such as genetic variations and environmental differences may be involved in gastric carcinogenesis [5]. For instance, it has appeared that only $1-2 \%$ of the infected will develop gastric cancer in their lifetime, albeit with more than half of the world's population being infected with $H$. pylori infection [6].

Gastric neoplasms are composed of cancer cells and other "non-cancer" compartments (including immune cells), which are the major players in gastric cancer disease progression and aggressiveness [7]. Tumour necrosis factor (TNF) is a pro-inflammatory cytokine, which is produced mainly by the immune cells such as macrophages, dendritic cells, lymphocytes and mast cells [8]. The tumour microenvironment, composed mainly of inflammatory cells, is a crucial player in the neoplastic process, fostering proliferation, survival and migration [9]. Thus, TNF-a may act as a tumour promoter through inflammation. Moreover, TNF-a can induce the transcription of a wide range of other proinflammatory cytokines and chemokines, amplifying the inflammatory cascade against the infection [2]. Individual studies reported the significant relationship between TNF- a -308 (rs 1800629) and the risk of gastric cancer [10, 11]. However, other studies reported differently [12-14]. The published reviews in this field [15-16], did not report the required information size leading to concerns over confidence in estimates. We have also found more individual studies on this. Taken together, the objective of this study was to summarize the evidence of association between TNF-a-308 and the risk of gastric cancer by meta-analysis of data from eligible studies.

\section{Materials And Methods}

This is a meta-analysis of genetic association studies (GAS), following the Plos One checklist (S 1 Table).

\section{Study search}

We searched relevant studies in the health-related databases of PubMed, Ovid Medline, Embase, Google scholar and Web of science. To maximize search scope, we used a simple term combination strategy: ("gastric cancer" OR "gastric carcinoma" OR "stomach cancer" OR gastric adenocarcinoma AND "tumour necrosis factor- alpha-308" OR "rs1800629" OR "TNF-a-308 G>A" OR “TNF-a-307 G>A"). The search strategy in PubMed database is provided (S2 Table). The search was limited to the publications in English until November 2020. We also manually searched the references of included studies and relevant systematic reviews to capture any additional studies.

\section{Inclusion criteria}

Human studies that assessed gastric cancer, irrespective of site or histological type were included, if they met all the following criteria:

1. The study investigated TNF- $a-308 \mathrm{G}>\mathrm{A}$ (rs 1800629) or TNF-a-307 G>A;

2. The study was a case-control design (retrospective or nested case-control); 
3. The study recruited healthy people as the controls;

4. The study assessed histopathologically confirmed gastric cancer as an outcome;

5. The study reported the genotype frequency in cases and controls;

6. The study provided sufficient data to compute odds ratio (OR) and its $95 \%$ confidence interval $(\mathrm{Cl})$ as the outcome measurement.

Gastric cancer is as defined in the primary studies. Studies which did not meet the inclusion criteria were excluded. Studies done on family or sibling-pairs were also excluded. Studies on gastric adenoma are not considered.

\section{Data extraction}

One investigator (WST) screened the titles and abstracts and selected the relevant full-text articles, following the inclusion criteria. Two investigators extracted the data (NHH, WST) from each study individually, by using a pretested data extraction sheet. Information collected included: first author, publication year, country, study setting, the number of cases/controls, ethnicity (Asian or Caucasians), method of genotyping and genotype/allele frequencies in cases/controls. If an allele frequency was zero in both case and control, we added 1 to that allele, following the Laplace approximation [17]. Any discrepancy between the two investigators was discussed with the third investigator (CN) to reach consensus.

\section{Assessment of the methodology quality}

The two investigators (WST, CN) independently evaluated the methodological quality of studies, using the Newcastle-Ottawa Scale (NOS) [18]. The assessment is based on the three domains such as 'selection of the study groups' (4 points), 'comparability of the groups' ( 2 points) and 'ascertainment of the exposure' (3 points). A total score for each study can vary from 0 (the worst) to 9 (the best). A score achieved $\geq 7,6-5$ or $\leq 4$ is regarded as good, moderate or low quality study, respectively. Any discrepancy between the two investigators was resolved by consensus.

\section{Statistical analysis}

We assessed Hardy-Weinberg equilibrium (HWE) in the control populations of the included studies using the goodness-of-fit test and p>0.05 was considered to indicate consistency with HWE [19]. As described elsewhere [20], the strength of the association between TNF-a-308 G>A and the risk of gastric cancer in each study was estimated using OR and its $95 \% \mathrm{Cl}$. Between- study heterogeneity was determined with the $R$ test, which indicates the percentage of total variation across studies attributed to the heterogeneity rather than chance. $\mathcal{R}$ values $>50 \%$ is regarded as substantial heterogeneity [21]. For pooling of the estimates, the summary ORs and its $95 \%$ Cls were calculated with the random-effects model (The Der Simonian and Laird method) in the presence of substantial heterogeneity. Otherwise, we used the fixed-effect model. We calculated the summary ORs and its $95 \%$ Cls in four genetic models: the allelic contrast model ( $A$ vs $G$ ), the dominant model ( $A A+G A$ vs $G G$ ), the recessive model (AA vs $G A+G G$ ), and the additive model (AA vs $G G$ ). In order to investigate the source of heterogeneity, subgroup analyses were employed under the dominant model for ethnicity, $H$. pylori infection status and study quality. Due to inconsistent reporting, we were unable to analyse by location or histological type of gastric cancer. For sensitivity analysis, we reassessed the relationship between TNF- a 308 and the risk of gastric cancer in all four genetic models only with studies in conformity of HWE. The publication bias was assessed by visual inspection of funnel plots under dominant model $[22,23]$.

\section{Trial sequential analysis}

To estimate the required information size, we performed trial sequential analysis (TSA) [24]. It is classified as 'firm evidence of effect' or 'potentially spurious evidence of effect', depending on whether the cumulative Z-curve cross the monitoring boundaries or not [23]. Meta-analysis was done with RevMan 5.3 (The Cochrane collaboration, Copenhagen) and rworldmap package in $R^{\circledR}$ version 3.6.1 (The $R$ Foundation). TSA plot was done with TSA software (Copenhagen Trial Unit, Centre for Clinical Intervention Research, Copenhagen).

\section{Results}

\section{Study search}

Fig 1 illustrates a four-phase study selection process. The initial search yielded a total of 1335 records. After removing the duplicates and screening of abstracts, 45 potentially eligible full-text articles that were retrieved. We included a final of 35 studies (with 11353 cases and 12827 controls) in this review [2, 5, 10-14, 25-52]. Summary of the 10 excluded studies were provided (S3 Table).

\section{Study characteristics}

Table 1 shows the characteristics of 35 studies identified. Of these, slightly more than half $(54.3 \%, 19 / 35)$ were from the Asian region. The years of publication spanned from 2001 to 2017 . The participants were adults with male predominance in all these studies. Eighty percent of the studies were consistent with HWE in genotype distribution of the controls.

The most frequent five studies were performed in China, South Korea or Brazil. Fig 2 shows geographical distribution of the studies included.

Of 35 studies, less than half $(40 \%, 14 / 35)$ were categorized as high quality in methodology (14 studies). Eight studies (22.8\%) were gastric adenocarcinomas. Only five studies provided $(2,10,13,34,44)$ anatomical location or histological type of gastric cancers. Twelve studies $(34 \%)$ used TaqMan 
method for genotyping. The majority of studies (24/35. 68.6\%) included H. pylori infected gastric cancer cases, albeit with variation in distribution. For instance, all cases (100\%) were infected with H. pylori in one study [32], while this was only $46 \%$ in another study [2] (Table 1).

\section{Effect estimations}

The genotype frequencies in individual studies are presented in Table 2. Overall, there were significant associations between TNF- $\mathrm{a}-308 \mathrm{G}>\mathrm{A}$ and the gastric cancer risk under the allele model (OR,1.17, 95\% Cl,1.0-1.38, $P: 80 \%)$ and the dominant model (OR,1.2, 95\% Cl:1.03-1.4, $P$ : 70\%), but not under the recessive model (OR, $1.1,95 \% \mathrm{Cl} ; 0.9-1.35, P: 16 \%)$ or the additive model (OR,1.25, 95\% Cl:1.01-1.54, $P: 0 \%)$. On stratification, only the Caucasian population showed susceptible to the gastric cancer risk under the allelic model (OR, 1.25, 95\% Cl,1.0-1.55, $P: 80 \%)$ and the dominant model (OR:1.24, 95\% Cl; $1.08-1.42$ P:40\%) (Fig 3A, Fig 3B, Fig 3C and Fig 3D).

\section{Subgroup analyses}

Under dominant model, TNF-a-308 G>A has significantly associated with an increased risk of gastric cancer with the high or moderate quality studies, but not with poor quality studies (S1 Fig). Based on 24 studies in which patients were infected with $\mathrm{H}$. pylori, a significant association was observed between TNF-a-308 G>A and gastric cancer risk (OR, 1.17, 95\% Cl, 1.05-1.29). On further stratification, this was only with the Caucasian group (OR, 1.17, 95\% Cl, 1.041.32) (Table 3).

A sensitivity analysis based on 28 studies that were consistent with HWE, showed TNF-a-308 G>A polymorphism was significantly associated with an increased risk of gastric cancer under the dominant model in overall analysis (OR, 1.19, 95\% Cl:1.1-1.29, $P: 37 \%)$, regardless of ethnic groups. Moreover, this association showed a decreased statistical heterogeneity (i.e. $P^{2}$ values from $69 \%$ to $37 \%$ ) (Table 3 , S2 Fig). In the allele and recessive model, there was no significant association in overall analysis even in the absence of statistical heterogeneity $(\mathcal{R}: 0 \%)$. Under the additive model, there was a significant association in overall analysis (OR, 1.31;95\% Cl:1.02-1.69, $\left.P^{2}: 0^{\%}\right)$, but not in any particular ethnic group (Table 3). A funnel plot showed no evidence of publication bias (S3 Fig).

\section{TSA plot}

We performed TSA of the dominant model with the use of an overall type I error of $5 \%$ and type II error of $20 \%$. The included total participants in this meta-analysis reached the required information size (for an expected RRR $26 \%$ ). Briefly, a TSA monitoring boundary crossed with $Z$ curve, confirms the presence of robust evidence (Fig 4). In such case further studies are not needed to provide sufficient information.

\section{Discussion}

\section{Summary information}

The present study provides evidence on the relationship between TNF-a-308 G>A and the risk of gastric cancer, comprising 11353 cases and 12827 controls from 35 individual studies. The major observations are as follows;

1. Based on 28 studies that met HWE, TNF-a-308 G>A SNP was significantly associated with the gastric cancer risk under the dominant and addictive models.

2. On stratification, the HWE status of the controls, ethnicity, pylori infection status or study quality had an impact on the effect estimates.

3. The TSA plot revealed that the required information size for evidence of effect was sufficient. Any future studies in this field will less likely change the direction of estimates.

The association was statistically significant only for the Caucasians in overall allele model, indicating a dominance of racial specific factors. This difference may be explained partly due to variations in the frequency of the A allele between the different ethnic groups that could contribute to the diverse results. Moreover, it might also be related to difference in environmental factors such as smoking and diet between these two major ethnic groups. This was indirectly supported by an individual study in Poland, in which $72 \%$ of the gastric cancer cases were smokers (ex-smokers or current smokers) [39] as the effects of inflammatory polymorphisms might have been masked by smoking [35]. Due to paucity of data, we were not able to perform subgroup analysis with the smoking status of participants included in the studies identified. A published meta-analyses [53] reported that $H$. pylori infected cases had higher risk of developing gastric cancer. This was also observed in the present review. This could be explained based on immune-biological plausibility. $H$. pylori infection activates the cytokines production in the lining of the stomach including inflammatory-related genes such as TNF- a in the present analysis.

Our findings were comparable with earlier reviews, in which the significant association was limited to the Caucasians [53, 54] in the dominant models [11, 54]. Although there are more studies in this analysis, the results in general, retained the evidence of association. The most commonly studied inflammatoryrelated genes in gastric diseases include TNF-a, among others. TNF-a has been shown to inhibit the gastric acid secretion which is important in inducing cell apoptosis and promoting epithelial cell damage [57] 


\section{Public health Implications}

The difference in association between the ethnic groups observed in the current analysis has implications. Studies had reported that the regulation of tumor immunity factors at the genetic and gene expression level may be different in the Asian and non-Asian gastric cancer populations, and this can affect the region-specific effects on therapy outcome and prognosis [58].

\section{Study limitations}

We acknowledge the study limitations. Only $36 \%$ of the studies in this review used TaqMan SNP genotyping assays, which is the preferred technology due to its high throughput and high accurate [59] compared to other methods. Hence, accuracy of genotype frequency is a concern. Some studies included were with small sample sizes. Hence, there might be type II statistical error. Meta-analysis is a retrospective pooling of published studies, and type II errors are, therefore, less likely than in individual studies.

There might be other confounding factors that were not included in our subgroup analyses. For example, infections with carcinogenic potentials (e.g. EBV) or smoking and alcohol drinking of the participants were not addressed due to limited data. This bias was likely to be pronounced as the calculations used unadjusted assessment of ORs. The effects of inflammatory polymorphisms might have been masked by smoking [35]. Moreover, it is likely to miss relevant studies that are available in non-English or non-indexed databases. Furthermore, there might be interactions of TNF-a and other genes such as interleukins (gene-gene interaction/synergism) or other potential confounding factors such as nutritional status and life style of the patients that might have significant roles in the gastric cancer risk. Due to limited number of studies, we could not perform pooled analysis with these potential confounding factors. Hence, findings in this meta-analysis should be interpreted with caution to these factors.

Nevertheless, there are strengths in our present meta-analysis study. More than half of the included studies were carried out in the Asia region, in which the gastric cancer was more prevalent. Moreover, the majority of gastric cancer patients in the primary studies identified were males. The current analysis reflected geographical and gender representativeness. The vast majority of included studies had evidence of HWE. Numerous studies had highlighted the issue of deviations from HWE in genetic association studies such as genotyping error, population admixture/substructure, among others [60-62]. Furthermore, for robustness of the findings, we have attempted several subgroup analyses. There are strengths in this meta-analysis compared with published reviews in this field [11, 53, 54, 60-63]. To be comprehensive, we have attempted the TSA technique, which is useful to adjust random-error risk. Moreover, we introduced TSA for confirmation of the estimates to assess a required information size. TSA plots indicated that there was sufficient information to provide conclusive results. An add-on TSA approach to this field will highlight to researchers the optimal sample size to make judgement of the effect estimates. This will help the researchers and policy makers to determine the need for future similar studies, which can save limited resources.

\section{Conclusions}

The current findings suggest that TNF- $a-308$ gene polymorphism plays an important role as host genetic factor predisposing to gastric carcinogenesis, and it could be useful as a screening marker. As the relationship of gastric cancer risk is ethnic specific, the consideration as a biomarker should be tailored to the specific population group. To substantiate this, studies only from the Asian regions, using more reliable genotyping technique are recommended.

\section{Declarations}

\section{Acknowledgements}

The authors gratefully acknowledge the participants and researchers of the primary studies. We thank our institutions for allowing us to perform this study.

\section{Ethics approval (and consent to participate)}

The need for approval was waived as this study solely used published human data.

\section{Consent for publication}

Not applicable.

\section{Availability of data and materials}

All data generated or analyzed during this study are included in this article and its supplementary information files.

\section{Competing interests}

The authors declare that they have no competing interests.

\section{References}

1. Ferlay J, Colombet M, Soerjomataram I, Mathers C, Parkin DM, Piñeros M. Estimating the global cancer incidence and mortality in 2018: GLOBOCAN sources and methods. Int J Cancer. 2019; 144(8):1941-53. 
2. El-Omar EM, Rabkin CS, Gammon MD, Vaughan TL, Risch HA, Schoenberg JB, et al. Increased risk of noncardia gastric cancer associated with proinflammatory cytokine gene polymorphisms. Gastroenterology. 2003; 124:1193-201.

3. Kelley JR, Duggan JM. Gastric cancer epidemiology and risk factors. J Clin Epidemiol. 2003; 56(1):1-9.

4. Ferlay J, Steliarova-Foucher E, Lortet-Tieulent J, Rosso S, Coebergh JW, Comber H. Cancer incidence and mortality patterns in Europe: estimates for 40 countries in 2012. Eur J Cancer. 2013; 49(6):1374-403.

5. Hong Y, Ge Z, Changrui Jing C, Shi J, Dong X, Zhou F, et al. Functional promoter -308G>A variant in tumor necrosis factor a gene is associated with risk and progression of gastric cancer in a Chinese population. PLoS One. 2013; 8(1):e50856.

6. Peleteiro B, Bastos A, Ferro A, Lunet N. Prevalence of Helicobacter pylori infection worldwide: a systematic review of studies with national coverage. Dig Dis Sci. 2014; 59(8):1698-709.

7. Tan P, Yeoh KG. Genetics and Molecular Pathogenesis of Gastric Adenocarcinoma. Gastroenterology. 2015; 149(5):1153-62.

8. Waters JP, Pober JS, Bradley JR. Tumour necrosis factor and cancer. J Pathol. 2013; 230:241-8.

9. Coussens LM, Werb Z. Inflammation and cancer. Nature. 2002; 420(6917):860-7.

10. Machado JC, Figueiredo C, Canedo P, Pharoah P, Carvalho R, Nabais S, et al. A proinflammatory genetic profile increases the risk for chronic atrophic gastritis and gastric carcinoma. Gastroenterology. 2003; 125:364-71.

11. Du LC, Gao R. Role of TNF-a -308G/A gene polymorphism in gastric cancer risk: A case control study and meta-analysis. Turk J Gastroenterol. 2017; 28(4):272-82.

12. Jang WH, Yang Yl, Yea SS, Lee YJ, Chun JH, Kim HI, et al. The -238 tumor necrosis factor-alpha promoter polymorphism is associated with decreased susceptibility to cancers. Cancer Lett. 2001; 166:41-6.

13. Glas J, Torok HP, Schneider A, Brunnler G, Kopp R, Albert ED, et al. Allele 2 of the interleukin-1 receptor antagonist gene is associated with early gastric cancer. J Clin Oncol. 2004; 22:4746-52.

14. Whiteman DC, Parmar P, Fahey P, Moore SP, Stark M, Zhao ZZ. Association of Helicobacter pylori infection with reduced risk for esophageal cancer is independent of environmental and genetic modifiers. Gastroenterology. 2010; 139:73- 83.

15. Gorouhi F, Islami F, Bahrami H, Kamangar F. Tumour-necrosis factor-A polymorphisms and gastric cancer risk: a meta-analysis. Br J Cancer. 2008; 98:1443-1451.

16. Yang JP, Hyun MH, Yoon JM, Park MJ, Kim D, Park S. Association between TNF-a-308 G/A gene polymorphism and gastric cancer risk: a systematic review and meta-analysis. Cytokine. 2014;70:104-114.

17. Naing C, Htet NH, Siew Tung W, Basavaraj AK, Mak JW (2018) Association of tumournecrosis factor-a(TNF-a) gene polymorphisms (-308 G>Aand -238 $\mathrm{G}>\mathrm{A}$ ) and the risk of severe dengue: A meta-analysis and trial sequential analysis. PLoSONE. 2018 Oct 9; 13(10):e0205413.

18. Wells BS GA, O'Connell D, Peterson J, Welch V, Losos MP. The Newcastle-Ottawa Scale (NOS) for assessing the quality of nonrandomised studies in metaanalyses 2014. http://www.ohri.ca/programs/ clinical_epidemiology/oxford.asp

19. Guo SW, Thompson EA. Performing the exact test of Hardy-Weinberg proportion for multiple alleles. Biometrics.1992; 48(2):361-72.

20. Thakkinstian A, McElduff P, D'Este C, Duffy D, Attia J. A method for meta-analysis of molecular association studies. Statistics in Medicine. 2005; 24(9): 1291-306.

21. Higgins J, Thomas J, Chandler J, Cumpston M, Li T, Page M, et al. Cochrane Handbook for Systematic Reviews of Interventions.

Available from: www.training.cochrane.org/handbook

22. Egger M, Smith GD, Schneider M, Minder C. Bias in meta-analysis detected by a simple, graphical test. BMJ. 1997; 315(7109):629-34.

23. Sterne JA, Egger M. Funnel plots for detecting bias in meta-analysis: guidelines on choice of axis. J Clin Epidemiol. 2001; 54(10):1046-55.

24. Brok J, Thorlund K, Wetterslev J, Gluud C. Apparently conclusive meta-analyses may be inconclusive-Trial sequential analysis adjustment of random error risk due to repetitive testing of accumulating data in apparently conclusive neonatal meta-analyses. Int J Epidemiol. 2009; 38(1):287-98.

25. Wu MS, Huang SP, Chang YT, Shun CT, Chang MC, Lin MT, et al. Tumor necrosis factor-alpha and interleukin-10 promoter polymorphisms in Epstein-Barr virus-associated gastric carcinoma. J Infect Dis. 2002; 185:106-9.

26. Fei BY, Xia B, Deng CS, Xia XQ, Xie M, Crusius JBA, et al. Association of tumor necrosis factor genetic polymorphism with chronic atrophic gastritis and gastric adenocarcinoma in Chinese Han population. World J Gastroenterol. 2004; 10:1256-61.

27. Lee SG, Kim B, Yook JH, Oh ST, Lee I, Song K. TNF/LTA polymorphisms and risk for gastric cancer/duodenal ulcer in the Korean population. Cytokine. $2004 ; 28: 75-82$.

28. Wu MS, Chen LT, Shun CT, Huang SP, Chiu HM, Wang HP, Lin MT, Cheng AL, Lin JT. Promoter polymorphisms of tumor necrosis factor-alpha are associated with risk of gastric mucosa-associated lymphoid tissue lymphoma. Int J Cancer. 2004; 110:695-700.

29. Garza-Gonzalez E, Bosques-Padilla FJ, El Omar E, Hold G, Tijerina-Menchaca R, Maldonado-Garza HJ, et al. Role of the polymorphic IL-1B, IL-1RN and TNFA genes in distal gastric cancer in Mexico. Int J Cancer. 2005; 114:237-41.

30. Lee JY, Kim HY, Kim KH, Kim SM, Jang MK, Park JY, et al. Association of polymorphism of IL-10 and TNF-A genes with gastric cancer in Korea. Cancer Lett. 2005; 225:207-14.

31. Li C, Xia B, Yang Y, Li J, Xia HH. TNF gene polymorphisms and Helicobacter pylori infection in gastric carcinogenesis in Chinese population. Am J Gastroenterol. 2005; 100:290-4.

32. Lu W, Pan K, Zhang L, Lin D, Miao X, You W. Genetic polymorphisms of interleukin (IL)-1B, IL-1RN, IL-8, IL-10 and tumor necrosis factor \{alpha\} and risk of gastric cancer in a Chinese population. Carcinogenesis. 2005; 26:631-6.

33. Perri F, Piepoli A, Bonvicini C, Gentile A, Quitadamo M, Di Candia M, et al. Cytokine gene polymorphisms in gastric cancer patients from two Italian areas at high and low cancer prevalence. Cytokine. 2005; 30(5):293-302.

34. Rocha GA, Guerra JB, Rocha AM, Saraiva IE, da Silva DA, de Oliveira CA, et al. IL1RN polymorphic gene and Cag A-positive status independently increase the risk of non-cardia gastric carcinoma. Int J Cancer. 2005; 115:678-83.

35. Zambon CF, Basso D, Navaglia F, Belluco C, Falda A, Fogar P, et al. Pro- and anti-inflammatory cytokines gene polymorphisms and Helicobacter pylori 
infection: Interactions influence outcome. Cytokine. 2005; 29:141-52.

36. Kamangar F, Abnet CC, Hutchinson AA, Newschaffer CJ, Helzlsouer K, Shugart YY, et al. Polymorphisms in inflammation-related genes and risk of gastric cancer (Finland). Cancer Causes Control. 2006; 17:117-25.

37. Kim N, Cho SI, Yim JY, Kim JM, Lee DH, Park JH, et al. (2006) The effects of genetic polymorphisms of IL-1 and TNF-A on Helicobacter pylori-induced gastroduodenal diseases in Korea. Helicobacter. 2006; 11:105-12.

38. Morgan DR, Dominguez RL, Keku TO, Heidt PE, Martin CF, Galanko JA, et al Gastric cancer and the high combination prevalence of host cytokine genotypes and Helicobacter pylori in Honduras. Clin Gastroenterol Hepatol. 2006; 4:1103-11.

39. Garcia-Gonzalez MA, Lanas A, Quintero E, Nicolas D, Parra-Blanco A, Strunk M, et al. Gastric cancer susceptibility is not linked to pro- and antiinflammatory cytokine gene polymorphisms in whites: a nationwide multicenter study in Spain. Am J Gastroenterol. 2007; 102:1878-92.

40. Hou L, El-Omar EM, Chen J, Grillo P, Rabkin CS, Baccarelli A, et al. Polymorphisms in Th1-type cell-mediated response genes and risk of gastric cancer. Carcinogenesis. 2007; 28:118-23.

41. Sugimoto M, Furuta T, Shirai N, Nakamura A, Xiao F, Kajimura M, Sugimura H, Hishida A. Different effects of polymorphisms of tumor necrosis factoralpha and interleukin-1 beta on development of peptic ulcer and gastric cancer. J Gastroenterol Hepatol. 2007; 22:51-9.

42. Canedo P, Duraes C, Pereira F, Regalo G, Lunet N, Barros H, et al. Tumor necrosis factor alpha extended haplotypes and risk of gastric carcinoma. Cancer Epidemiol Biomarkers Prev. 2008; 17:2416-20.

43. Crusius JB, Canzian F, Capella G, Peña AS, Pera G, Sala N, et al. Cytokine gene polymorphisms and the risk of adenocarcinoma of the stomach in the European prospective investigation into cancer and nutrition (EPIC-EURGAST). Ann Oncol. 2008; 19:1894-902.

44. Melo Barbosa HP, Martins LC, dos Santos SE, Demachki S, Assumpção MB, et al. Interleukin-1 and TNF-a polymorphisms and Helicobacter pylori in a Brazilian Amazon population. World J Gastroenterol. 2009; 15(12): 1465-71.

45. Yang JJ, Ko KP, Cho LY, Shin A, Gwack J, Chang SH, et al. The role of TNF genetic variants and the interaction with cigarette smoking for gastric cancer risk: a nested case-control study. BMC Cancer. 2009; 9:238.

46. Burada F, Angelescu C, Mitrut P, Ciurea T, Cruce M, Saftoiu A, et al. Interleukin-4 receptor $-3223 T \rightarrow$ C polymorphism is associated with increased gastric adenocarcinoma risk. Can J Gastroenterol. 2012; 26:532-6.

47. Santos JC, Ladeira MS, Pedrazzoli J, Jr, Ribeiro ML. Relationship of IL-1 and TNF-a polymorphisms with Helicobacter pylori in gastric diseases in a Brazilian population. Braz J Med Biol Res. 2012; 45:811-7.

48. Oliveira JG, Duarte MC, Silva AE. IL-1ra anti-inflammatory cytokine polymorphism is associated with risk of gastric cancer and chronic gastritis in a Brazilian population, but the TNF- $\beta$ pro-inflammatory cytokine is not. Mol Biol Rep. 2012; 39:7617-25.

49. Bhayal AC, Krishnaveni D, RangaRao KP, Bogadi V, Suman C, Jyothy A, et al. Role of tumor necrosis factor-a -308 G/A promoter polymorphism in gastric cancer. Saudi J Gastroenterol. 2013; 19(4):182-6.

50. Yu T, Lu Q, Ou XL, Cao DZ, Yu Q. Clinical study on gastric cancer susceptibility genes IL-10-1082 and TNF-a. Genet Mol Res. 2014; 13(4):10909-12.

51. Stubljar D, Jeverica S, Jukic T, Skvarc M, Pintar T, Tepes B, et al. The influence of cytokine gene polymorphisms on the risk of developing gastric cancer in patients with Helicobacter pylori infection. Radiol Oncol. 2015; 49(3):256-64.

52. Zabaglia LM, Ferraz MA, Pereira WN, Orcini WA, de Labio RW, Neto AC et al. Lack of association among TNF-a gene expression, -308 polymorphism (G>A) and virulence markers of Helicobacter pylori. J Venom Anim Toxins Incl Trop Dis. 2015; 21: 54.

53. Gorouhi F, Islami F, Bahrami H, Kamangar F. Tumour-necrosis factor-A polymorphisms and gastric cancer risk: a meta-analysis. Br J Cancer. 2008; 98:1443-51.

54. Yang JP, Hyun MH, Yoon JM, Park MJ, Kim D, Park S. Association between TNF-a-308 G/A gene polymorphism and gastric cancer risk: a systematic review and meta-analysis. Cytokine. 2014; 70:104-14.

55. Zhao L, Zhang F, Ding X, Wu G, Lam YY, Wang X, et al. Gut bacteria selectively promoted by dietary fibers alleviate type 2 diabetes. Science. 2018; 359(6380):1151-6.

56. Genta RM. The immunobiology of Helicobacter pylori gastritis. Semin Gastrointest Dis. 1997; 8(1):2-11.

57. Beales IL, Calam J. Interleukin 1 beta and tumour necrosis factor alpha inhibit acid secretion in cultured rabbit parietal cells by multiple pathways. Gut. $1998 ; 42: 227-234$

58. Sunakawa Y, Lenz HJ. Molecular classification of gastric adenocarcinoma: translating new insights from the cancer genome atlas research network. Curr Treat Options Oncol. 2015; 16(4):17.

59. Shen GQ, Abdullah KG, Wang QK. The TaqMan method for SNP genotyping. Methods Mol Biol. 2009; 578:293-306.

60. Zheng W, Zhang S, Zhang S, Min L, Wang Y, Xie J, et al. The relationship between tumor necrosis factor-a polymorphisms and gastric cancer risk: An updated meta-analysis. Biomed Rep. 2017; 7(2): 33-42.

61. Guo XF, Wang J, Yu SJ, Guo XF, Wang J, Yu SJ, et al. TNF-a-308 polymorphism and risk of digestive system cancers: a meta-analysis. World J

Gastroenterol. 2013; 19:9461-71.

62. Zhu F, Zhao H, Tian X, Meng X. Association between tumor necrosis factor-a rs1800629 polymorphism and risk of gastric cancer: a meta-analysis. Tumour Biol. 2014; 35:1799-803.

63. Jiang X, Naikoo NA, Gao S. A meta-analysis of tumor necrosis factor-a-308 G>A polymorphism in gastric cancer, Asian Biomedicine. 2020; 14(3):91-96.

\section{Tables}

Table 1. Characteristics of the studies included in the meta-analysis 


\begin{tabular}{|c|c|c|c|c|c|c|c|c|c|c|c|c|c|}
\hline & $\begin{array}{l}\text { Author, } \\
\text { Year }\end{array}$ & $\begin{array}{l}\text { Ref } \\
\text { no. }\end{array}$ & Country & Ethnicity & $\begin{array}{l}\text { Cases/ } \\
\text { Controls }\end{array}$ & $\begin{array}{l}\text { Age } \\
\text { group }\end{array}$ & Males & $\begin{array}{l}\text { Type } \\
\text { of } \\
\text { cancer }\end{array}$ & Smokers & $\begin{array}{l}\text { Study } \\
\text { design }\end{array}$ & $\begin{array}{l}\text { Genotyping } \\
\text { method }\end{array}$ & $\begin{array}{l}\text { HP } \\
\text { +ve }\end{array}$ & $\begin{array}{l}\text { HWE, } \\
p \text { value }\end{array}$ \\
\hline 1 & $\begin{array}{l}\text { El-Omar, } \\
2003\end{array}$ & 2 & USA & Caucasian & $314 / 210$ & adult & $\begin{array}{l}87 \% \\
77 \%\end{array}$ & $\begin{array}{l}\text { GC-C } \\
\text { GC- } \\
\text { NC }\end{array}$ & $\begin{array}{l}\text { Yes } \\
(80 \%)\end{array}$ & $\mathrm{CC}$ & TaqMan & $46 \%$ & 0.548 \\
\hline 2 & $\begin{array}{l}\text { Hong, } \\
2013\end{array}$ & 5 & China & Asian & $1686 / 1894$ & adult & $73 \%$ & $\begin{array}{l}\text { GC-C } \\
\text { GC- } \\
\text { NC }\end{array}$ & NA & $\mathrm{CC}$ & TaqMan & NA & 0.376 \\
\hline 3 & $\begin{array}{l}\text { Machado, } \\
2003\end{array}$ & 10 & Portugal & Caucasian & $287 / 306$ & adult & $58.3 \%$ & $\mathrm{GC}$ & NA & $\mathrm{CC}$ & PCR & $61.3 \%$ & 0.649 \\
\hline 4 & Du, 2017 & 11 & China & Asian & $400 / 400$ & adult & $70 \%$ & $\overline{\mathrm{GC}}$ & Yes & $\begin{array}{l}\text { CC, } \\
\text { MA }\end{array}$ & $\begin{array}{l}\text { allele- } \\
\text { specific } \\
\text { PCR }\end{array}$ & NA & 0.000 \\
\hline 5 & Jang, 2001 & 12 & $\begin{array}{l}\text { South } \\
\text { Korea }\end{array}$ & Asian & $52 / 92$ & adult & NA & GAC & NA & $\mathrm{CC}$ & $\begin{array}{l}\text { Nested } \\
\text { PCR }\end{array}$ & NA & 0.704 \\
\hline 6 & Glas, 2004 & 13 & Germany & Caucasian & $88 / 145$ & adult & $46.6 \%$ & $\mathrm{GC}$ & $\overline{\mathrm{NA}}$ & $\overline{\mathrm{CC}}$ & $\overline{\text { PCR }}$ & $88 \%$ & 0.669 \\
\hline 7 & $\begin{array}{l}\text { Whiteman, } \\
2010\end{array}$ & 14 & Australia & Caucasian & $307 / 1355$ & adult & $88 \%$ & GAC & $76 \%$ & $\mathrm{CC}$ & $\overline{\text { PCR }}$ & $25 \%$ & 0.979 \\
\hline 8 & Wu, 2002 & 25 & Taiwan & Asian & $120 / 220$ & adult & NA & $\mathrm{GC}$ & NA & $\overline{\mathrm{CC}}$ & $\begin{array}{l}\text { PCR, } \\
\text { dir seq }\end{array}$ & NA & 0.000 \\
\hline 9 & Fei, 2004 & 26 & China & Asian & $56 / 164$ & & $76.8 \%$ & GAC & NA & $\mathrm{CC}$ & PCR & NA & 0.743 \\
\hline 10 & Lee, 2004 & 27 & $\begin{array}{l}\text { South } \\
\text { Korea }\end{array}$ & Asian & $341 / 261$ & adult & $58.4 \%$ & $\mathrm{GC}$ & NA & $\mathrm{CC}$ & PCR & NA & 0.493 \\
\hline 11 & $\mathrm{Wu}, 2004$ & 28 & Taiwan & Asian & $204 / 210$ & adult & $61.8 \%$ & GAC & NA & $\overline{\mathrm{CC}}$ & $\begin{array}{l}\text { PCR, dir } \\
\text { seq }\end{array}$ & $80.4 \%$ & 0.000 \\
\hline 12 & $\begin{array}{l}\text { Garcia- } \\
\text { Gonzalez, } \\
2005\end{array}$ & 29 & Spain & Caucasian & $63 / 215$ & adult & $64.1 \%$ & $\mathrm{GC}$ & NA & $\mathrm{CC}$ & PCR & $49.2 \%$ & 0.607 \\
\hline 13 & Lee, 2005 & 30 & $\begin{array}{l}\text { South } \\
\text { Korea }\end{array}$ & Asian & $122 / 120$ & adult & $59 \%$ & $\mathrm{GC}$ & NA & $\mathrm{CC}$ & PCR & $81 \%$ & 0.403 \\
\hline 14 & Li, 2005 & 31 & \begin{tabular}{|l} 
China \\
\end{tabular} & Asian & $59 / 264$ & adult & $66.1 \%$ & $\begin{array}{l}\text { GC- } \\
\text { NC }\end{array}$ & NA & $\mathrm{CC}$ & PCR-RFLP & $93.2 \%$ & 0.559 \\
\hline 15 & Lu, 2005 & 32 & China & Asian & $250 / 300$ & adult & $73.2 \%$ & $\mathrm{GC}$ & $57.2 \%$ & $\mathrm{CC}$ & $\overline{\text { PCR }}$ & $70.4 \%$ & 0.559 \\
\hline 16 & $\begin{array}{l}\text { Perri, } \\
2005\end{array}$ & 33 & Italy & Caucasian & $184 / 366$ & adult & $59.8 \%$ & GAC & NA & $\mathrm{CC}$ & PCR & 77.1 & 0.145 \\
\hline 17 & $\begin{array}{l}\text { Rocha, } \\
2005\end{array}$ & 34 & Brazil & Caucasian & $166 / 536$ & adult & \begin{tabular}{|l|}
$69.9 \%$ \\
\end{tabular} & $\begin{array}{l}\text { GC- } \\
\text { NC }\end{array}$ & NA & $\mathrm{CC}$ & PCR-RFLP & $100 \%$ & 0.345 \\
\hline 18 & $\begin{array}{l}\text { Zambo, } \\
2005\end{array}$ & 35 & Italy & Caucasian & $\begin{array}{l}\text { 129/792 } \\
\text { (benign } \\
\text { gastro- } \\
\text { duodenal } \\
\text { diseases) }\end{array}$ & adult & $60.5 \%$ & $\begin{array}{l}\text { GC- } \\
\text { NC }\end{array}$ & NA & $\mathrm{CC}$ & Taqman & $84 \%$ & 0.909 \\
\hline 19 & $\begin{array}{l}\text { Kamangar, } \\
2006\end{array}$ & 36 & Finland & Caucasian & $112 / 208$ & adult & $100 \%$ & $\mathrm{GC}$ & $100 \%$ & $\mathrm{CC}$ & Taqman & $\begin{array}{l}91 \% \\
\text { (NC); } \\
68 \% \\
(\mathrm{C})\end{array}$ & 0.292 \\
\hline 20 & Kim, 2006 & 37 & $\begin{array}{l}\text { South } \\
\text { Korea }\end{array}$ & Asian & $237 / 474$ & adult & 62.9 & $\mathrm{GC}$ & NA & $\mathrm{CC}$ & $\begin{array}{l}\text { Taqman } \\
\text { and PCR- } \\
\text { RFLP }\end{array}$ & $86.5 \%$ & 0.911 \\
\hline 21 & $\begin{array}{l}\text { Morgan, } \\
2006\end{array}$ & 38 & Honduras & Caucasian & $170 / 162$ & adult & $69 \%$ & $\mathrm{GC}$ & NA & $\mathrm{CC}$ & TaqMan & $80 \%$ & 0.623 \\
\hline 22 & $\begin{array}{l}\text { Garcia- } \\
\text { Gonzalez, } \\
2007\end{array}$ & 39 & Spain & Caucasian & $404 / 404$ & adult & $65.8 \%$ & $\mathrm{GC}$ & Yes & $\mathrm{CC}$ & TaqMan & $70.3 \%$ & 0.35 \\
\hline 23 & Hou, 2007 & 40 & Poland & Caucasian & $305 / 427$ & adult & $66.2 \%$ & $\mathrm{GC}$ & $\begin{array}{l}\text { Yes } \\
(71.1 \%)\end{array}$ & $\mathrm{CC}$ & TaqMan_ & NA & 0.186 \\
\hline 24 & $\begin{array}{l}\text { Sugimoto, } \\
2007\end{array}$ & 41 & Japan & Asian & $105 / 172$ & adult & $80.9 \%$ & $\mathrm{GC}$ & NA & $\mathrm{CC}$ & PCR-RFLP & $100 \%$ & 0.908 \\
\hline
\end{tabular}




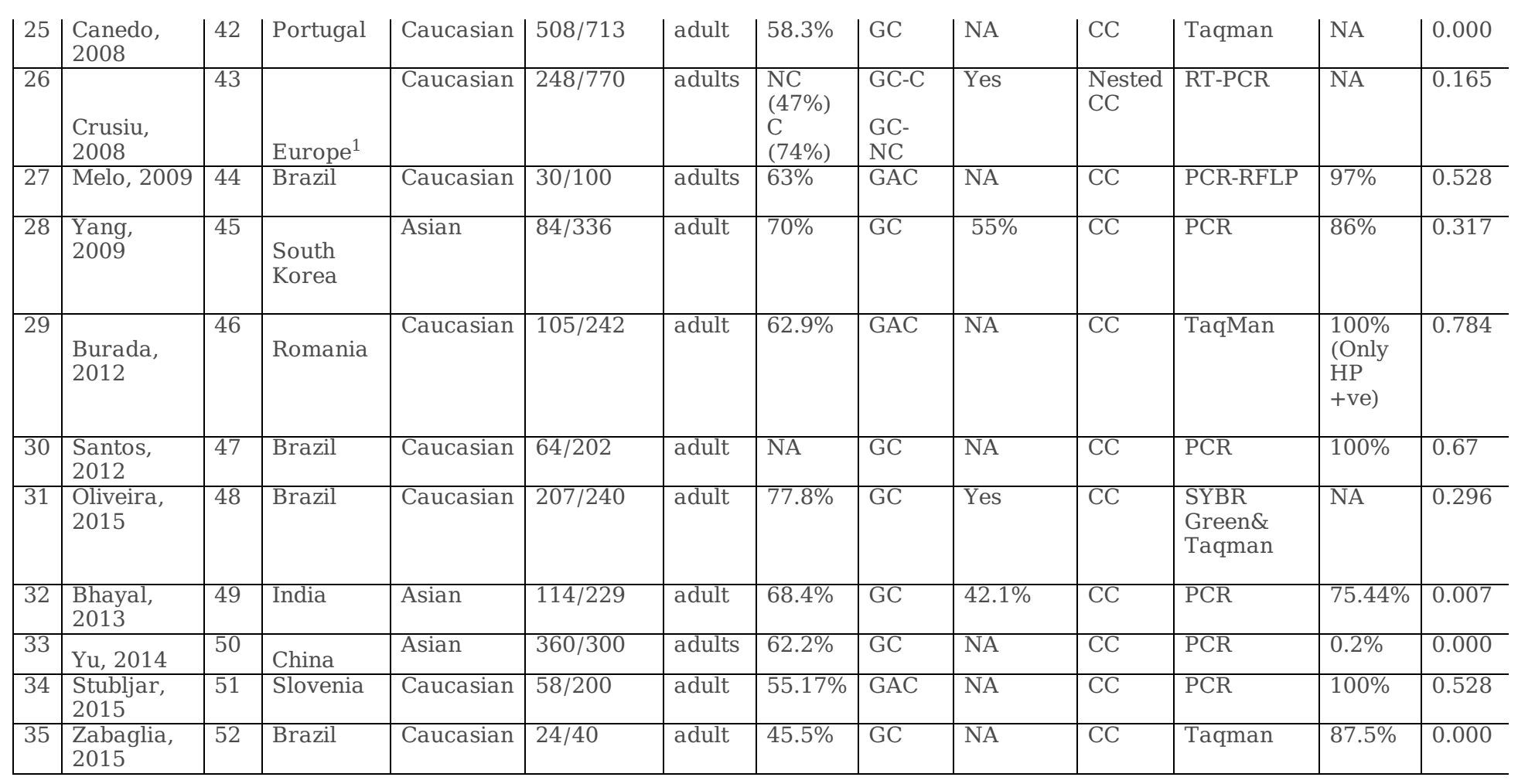

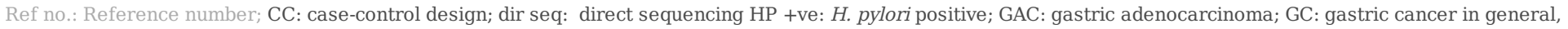

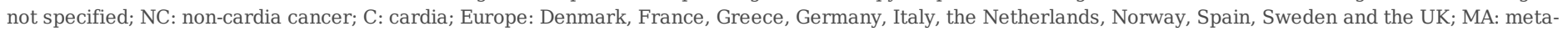
analysis; HWE: Hardy-Weinberg Equilibrium; NOS criteria: 0-9 score; RT-PCR: Real-time PCR; NA: not available/not reported/not shown.

Table 2: Distribution of gene frequencies in the studies

\begin{tabular}{|l|l|l|c|c|c|c|c|c|}
\hline \multicolumn{1}{|c|}{ Study } & Year & Ref. No. & \multicolumn{3}{|c|}{ Cases } & \multicolumn{3}{c|}{ Controls } \\
\cline { 4 - 9 } & & & G/G & G/A & A/A & G/G & G/A & A/A \\
\hline Jang & 2001 & 12 & 46 & 4 & 2 & 85 & 7 & 0 \\
\hline Wu & 2002 & 24 & 96 & 17 & 7 & 180 & 27 & 13 \\
\hline El-Omar & 2003 & 2 & 201 & 87 & 26 & 152 & 52 & 6 \\
\hline Machado & 2003 & 10 & 179 & 105 & 3 & 231 & 69 & 4 \\
\hline Fei & 2004 & 25 & 53 & 3 & 0 & 143 & 20 & 1 \\
\hline Glas & 2004 & 13 & 66 & 19 & 3 & 105 & 36 & 4 \\
\hline Lee & 2004 & 26 & 218 & 43 & 1 & 297 & 42 & 1 \\
\hline Wu & 2004 & 27 & 163 & 29 & 12 & 171 & 26 & 13 \\
\hline Garcia-Gonzalez & 2005 & 28 & 0 & 8 & 55 & 1 & 35 & 179 \\
\hline Lee & 2005 & 29 & 112 & 10 & 0 & 103 & 17 & 0 \\
\hline Li & 2005 & 30 & 55 & 4 & 0 & 228 & 34 & 2 \\
\hline Lu & 2005 & 31 & 214 & 36 & 0 & 274 & 24 & 2 \\
\hline Perri & 2005 & 32 & 71 & 14 & 1 & 118 & 24 & 4 \\
\hline Rocha & 2005 & 33 & 120 & 37 & 4 & 399 & 123 & 13 \\
\hline Zambo & 2005 & 34 & 95 & 31 & 3 & 496 & 138 & 10 \\
\hline Kamangar & 2006 & 35 & 86 & 23 & 3 & 154 & 52 & 2 \\
\hline Kim & 2006 & 36 & 199 & 34 & 4 & 400 & 59 & 2 \\
\hline Morgan & 2006 & 37 & 151 & 17 & 0 & 149 & 12 & 0 \\
\hline Garcla-Gonzalez & 2007 & 38 & 309 & 84 & 11 & 320 & 77 & 7 \\
\hline Hou & 2007 & 39 & 186 & 98 & 21 & 304 & 109 & 15 \\
\hline Sugimoto & 2007 & 40 & 101 & 4 & 0 & 169 & 3 & 0 \\
\hline Canedo & 2008 & 41 & 330 & 178 & 0 & 544 & 169 & 0 \\
\hline Crusiu & 2008 & 42 & 170 & 64 & 2 & 820 & 274 & 31 \\
\hline Melo & 2009 & 43 & 24 & 5 & 1 & 86 & 13 & 1 \\
\hline Yang & 2009 & 44 & 75 & 8 & 0 & 288 & 34 & 0 \\
\hline Whiteman & 2010 & 14 & 196 & 93 & 6 & 842 & 403 & 48 \\
\hline Burada & 2010 & 45 & 78 & 26 & 1 & 196 & 44 & 2 \\
\hline Santos & 2012 & 46 & 44 & 20 & 0 & 22 & 4 & 0 \\
\hline Bhayal & 2013 & 47 & 32 & 76 & 6 & 76 & 128 & 25 \\
\hline Hong & 2013 & 5 & 1335 & 333 & 18 & 1585 & 295 & 14 \\
\hline Oliveira & 2015 & 48 & 138 & 66 & 3 & 167 & 69 & 4 \\
\hline Zabaglia & 2015 & 49 & 17 & 4 & 3 & 33 & 4 & 3 \\
\hline Du & 2017 & 11 & 204 & 184 & 12 & 326 & 60 & 14 \\
\hline & & & & & & & & \\
\hline
\end{tabular}


Table 3 Subgroup analysis

\begin{tabular}{|c|c|c|c|c|}
\hline \multirow{2}{*}{ Genetic model } & \multirow[t]{2}{*}{ Number of studies included } & \multicolumn{3}{|l|}{ OR ( $95 \% \mathrm{CI})$} \\
\hline & & Overall & Asians & Caucasians \\
\hline Studies consistent with HWE & $\begin{array}{l}28 \\
\text { (Asians } 10+\text { Caucasians 18) }\end{array}$ & & & \\
\hline Allele & & $\begin{array}{l}1.11 \\
{[0.97,1.27] \mathrm{R}}\end{array}$ & $\begin{array}{l}1.06 \\
{[0.81,1.39] \mathrm{R}}\end{array}$ & $\begin{array}{l}1.12 \\
{[0.95,1.33] \mathrm{R}}\end{array}$ \\
\hline Dominant & & $\begin{array}{l}1.19 \\
{[1.10,1.29] \mathrm{F}}\end{array}$ & $\begin{array}{l}1.20 \\
{[1.05,1.38] \mathrm{F}}\end{array}$ & $\begin{array}{l}1.19 \\
{[1.07,1.31] \mathrm{F}}\end{array}$ \\
\hline Recessive & & $\begin{array}{l}1.24 \\
{[0.98,1.56] \mathrm{F}}\end{array}$ & $\begin{array}{l}1.50 \\
{[0.88,2.55] \mathrm{F}}\end{array}$ & $\begin{array}{l}1.18 \\
{[0.90,1.53] \mathrm{F}}\end{array}$ \\
\hline Additive & & $\begin{array}{l}1.31 \\
{[1.02,1.69] \mathrm{F}}\end{array}$ & $\begin{array}{l}1.53 \\
{[0.91,2.56] \mathrm{F}}\end{array}$ & $\begin{array}{l}1.25 \\
{[0.94,1.67] \mathrm{F}}\end{array}$ \\
\hline Studies based on $H$. Pylori infection status & $\begin{array}{l}24 \\
\text { (Asians } 8 \text { + Caucasians 16) }\end{array}$ & & & \\
\hline Dominant & & $\begin{array}{l}1.17 \\
{[1.05,1.29]} \\
F\end{array}$ & $\begin{array}{l}1.15 \\
{[0.93,1.42]} \\
\mathrm{F}\end{array}$ & $\begin{array}{l}1.17 \\
{[1.04,1.32]} \\
F\end{array}$ \\
\hline
\end{tabular}

HWE: Hardy-Weinberg equilibrium; F : Fixed- effect model; R: random-effects model; Significant association is in bold;

\section{Figures}
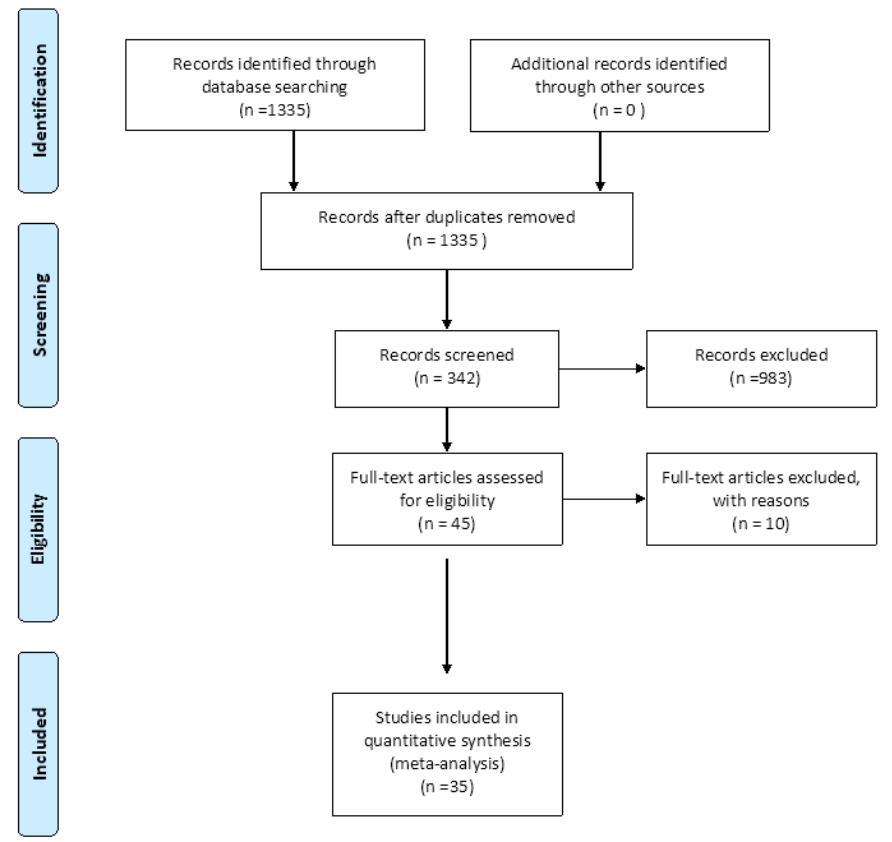

$$
\begin{aligned}
& \text { Studies included in } \\
& \text { quantitative synthesis } \\
& \text { (meta-analysis) } \\
& (n=35)
\end{aligned}
$$




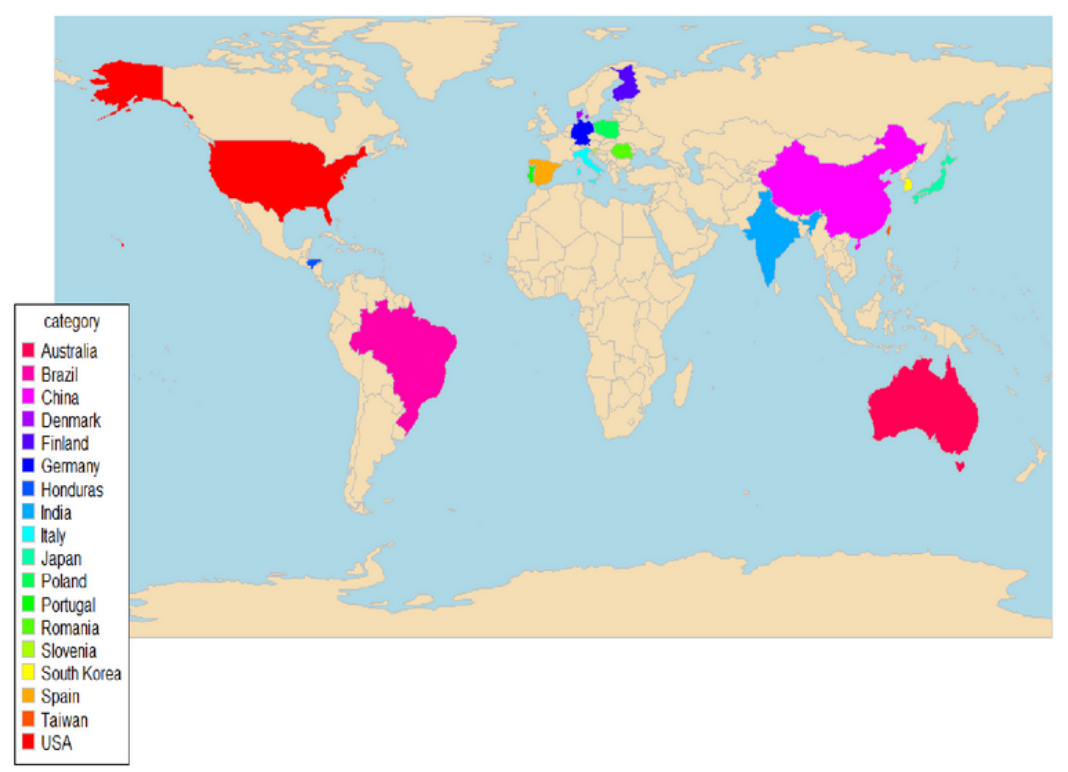

\section{Figure 2}

Geographical distribution of included studies. Note: The designations employed and the presentation of the material on this map do not imply the expression of any opinion whatsoever on the part of Research Square concerning the legal status of any country, territory, city or area or of its authorities, or concerning the delimitation of its frontiers or boundaries. This map has been provided by the authors. 
A)

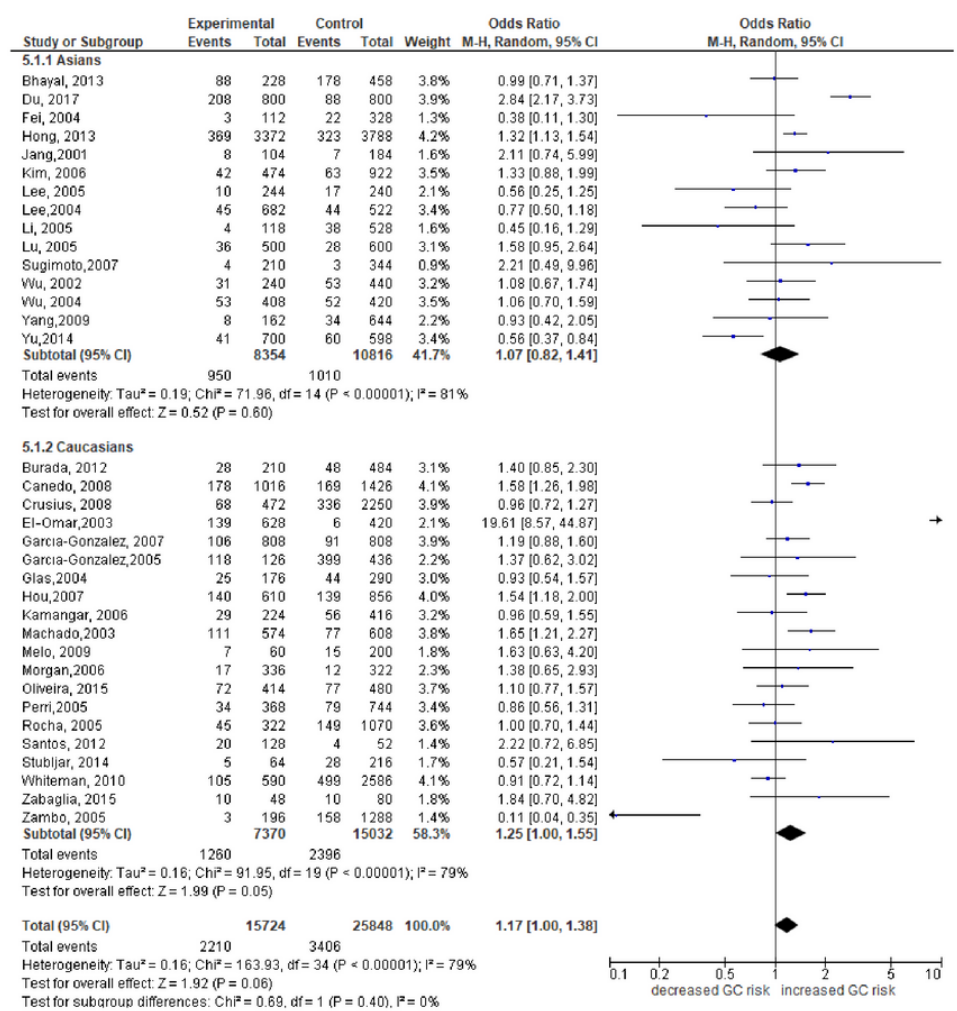

B)

\section{Figure 3}

Forest plot of gastric cancer risk associated with TNF-a 308 G/A polymorphism by ethnic group. (A) Allelic model. (B) Dominant model. (C) Recessive model. (D) Additive model Footnote: The circle and horizontal lines correspond to the study-specific OR and $95 \% \mathrm{Cl}$. The diamond represents the summary OR and 95\% Cl. 


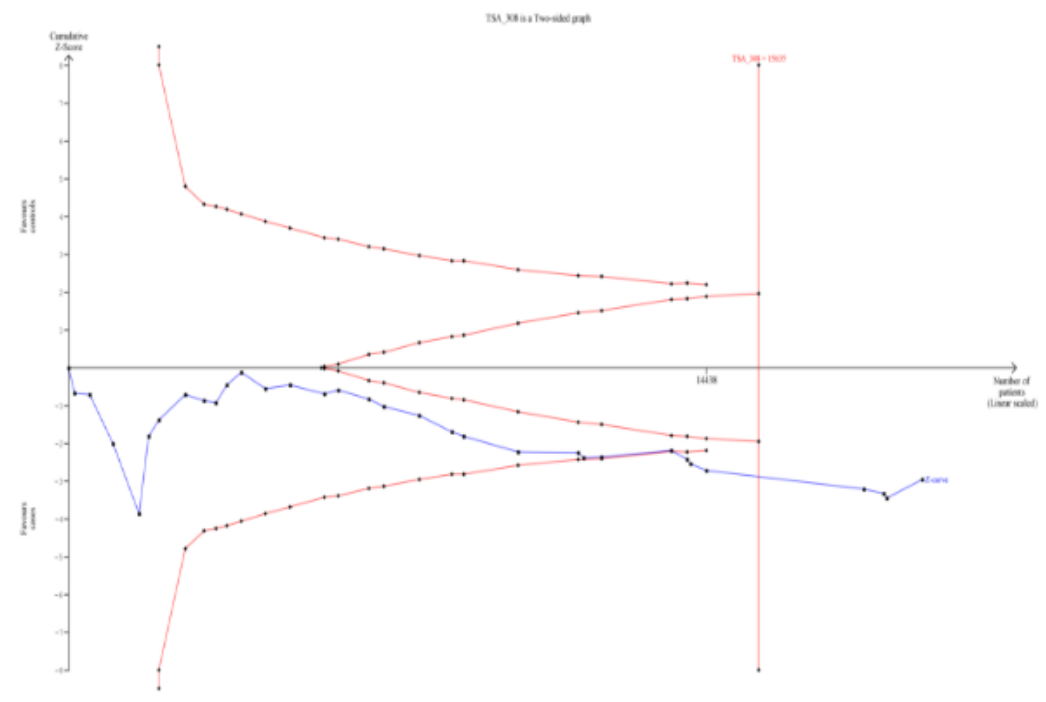

Figure 4

Trial sequential monitoring plot of TNF- $a-308$ in gastric cancer risk under dominant model

\section{Supplementary Files}

This is a list of supplementary files associated with this preprint. Click to download.

- S1TablePLOSONEChecklist.doc

- S2Table.doc

- S3Table.doc

- S1Figure.doc

- S2Figure.doc

- S3Fig.doc 